\title{
A proteção da cultura ao sujeito tran- seunte: uma entrevista com Jorge Terena
}

\section{The protection of the culture of the passing subject: an interview with Jorge}

Terena

\author{
Mônica Thereza Soares Pechincha
}

Resumo: $\mathrm{O}$ artigo tem por objetivo apresentar a interpretação de Jorge Terena sobre as circunstâncias de sua entrada prematura e inserção duradoura no mundo evangélico e de seu rompimento definitivo com o credo e com a missão. A análise procedida tem em vista, como temas de fundo, controvérsias antropológicas em torno da questão da conversão indígena bem como a relação entre trânsito religioso e descolonização.

Palavras-chave: Religião; identidade; discurso indígena.

Abstract: The article aims at presenting the interpretation of Jorge Terena of the circumstances of his premature entrance and lasting insertion into the evangelical world and of his definitive break with the belief and with the mission. The arising analysis has in mind, as basic themes, anthropoligical controversies around the question of the indigenous conversion as well as the relaltionship between religious transit and decolonization.

Key words: Religion; identity; indigenous discourse.

Doutora em antropologia, professora do Programa de Mestrado em Desenvolvimento Local da Universidade Católica Dom Bosco, onde atua em projeto de educação indígena voltado para os Kadiwéu e os Terena. natecogota@ig.com.br 
Aproximei-me de Jorge Terena ${ }^{1}$ para a entrevista sobre a qual aqui reflito motivada pelo interesse que tinha em pensar processos de trânsito religioso e os conflitos neles vividos por sujeitos étnicos ${ }^{2}$. A trajetória de vida de Jorge Terena oferecia um enredo rico, complexo, exemplar e condensador de uma experiência que, embora individual, é alegórica de uma experiência social, coletiva e histórica. Jorge viveu um trânsito religioso, movimento que, no caso, também implicou uma diáspora individual. $\mathrm{O}$ eixo da entrevista foi a intensa e longa relação de Jorge com o universo evangélico, que se iniciou na infância, e transcorreu até a sua maturidade. Nesta trajetória, Jorge desejou ser um missionário e se preparou para tanto, mas, em certo momento, rompeu definitivamente com a igreja e despontou como um líder indígena de expressão nacional.

Em histórias como a de Jorge, a religiosidade conflui com a etnicidade e era cabível perguntar sobre como estas duas instâncias convergiam e se atualizavam na sua fala, na presunção tanto da influência do doutrinamento cristão a que se submeteu, quanto do movimento de desligamento que realizou. Os episódios de sua história marcados pela relação, sua e de seu povo, com o empreendimento missionário e civilizatório, abria um leque de questões que continuam a alimentar a reflexão sobre processos identitários atuais.

Muitas análises já foram dedicadas àquilo que se passa com os povos ou indivíduos indígenas no terreno do que, na antropologia, entendemos por etnicidade, e muito já foi dito sobre as inflexões dos discursos de líderes indígenas quando eles entram no embate político com a sociedade nacional. Em regra essas análises referem esse discurso étnico à criatividade interpretativa fundada nas cosmologias indígenas ${ }^{3}$, contrapondose a qualquer suspeita de mera incorporação por aqueles dos discursos genéricos, construtores de um lugar, de uma posição e de um reconhecimento para os indígenas, mesmo os pretensamente em defesa da sua diferença. Criatividade análoga, no que diz respeito à apresentação da diferença indígena, é observada nos casos de emergência étnica e reelaboração cultural ou ressurgência ${ }^{4}$, sem, entretanto, o recurso de cosmologias originais operantes das quais esta diferença não é dependente, mas insistindo, todavia, no vínculo a um passado ocultado por força do contato. Guardando as peculiaridades entre estas interpretações, o que importa reter é a persistência ou a produção da diferença, considerando toda a complexidade dos entrecruzamentos entre os processos próprios de subjetivação indígena e o ocidental.

Há uma insistência muito legítima na antropologia indígena no Brasil de que - com a certeza de que os índios não foram sujeitos que se 
deixaram subjugar passivamente à colonização, em suas diversas frentes, como a missionária - a diferença indígena seja percebida como imperando, da perspectiva indígena, naquela relação. O que está em jogo neste viés, ou o que se faz antropologicamente relevante, não é apenas constatar a violência da interferência no mundo indígena, que é inegável, mas desvelar as razões, os sentidos, os significados, as formas e as práticas próprias deste mundo, denegadas pela empresa civilizatória ocidental. Adianto que o discurso de Jorge Terena segue o inverso desta lógica.

Os processos de "conversão" indígena aos credos cristãos, nessa mesma senda da agência indígena, têm sido analisados, por alguns, pela via das incongruências na relação dos índios com o cristianismo, observadas seja na rejeição - salvo engano, sempre parcial - ou na fácil conversão e desconversão - lembrando que esses próprios termos são colocados, às vezes em questão. Estudo seminal a respeito é o de Viveiros de Castro sobre a inconstância tupinambá, perfeito em reiterar a não transparência para nós do que os índios estão fazendo quando interpretam os termos do civilizador, e em questionar a categoria "crença", incorporada na leitura antropológica dos fatos culturais e, por conseguinte, imputada aos ameríndios (1992 e também 2002, p. 390-1, para a relação entre crença e corpo). Trabalho especialmente exemplar desta linha é o de Vilaça (1996; 2007), que mostra as surpreendentes inversões operadas pelos wari na reelaboração dos significados cristãos à luz da sua sociologia, fatos que desacreditam qualquer pretensão missionária da correspondência simples na tradução dos seus ensinamentos.

De outro modo, há estudos destas relações que se pautam nas correspondências, conexões e significações compartilhadas que se formaram entre indígenas e missões. Três coletâneas de estudos sobre o tema, de publicação relativamente recente (Wright, 1999 e 1004; Montero, 2006), nas quais se aborda tanto o cristianismo católico quanto o evangélico dos/entre os indígenas, nos permitem uma visão de conjunto - com ampla representação de povos indígenas e circunstâncias - destas duas tendências analíticas. Detenho-me sobre as propostas teóricas dos organizadores destas obras, que bem qualificam o estado da arte.

O mote de Wright é a conversão, remetendo a definição do conceito aos "múltiplos sentidos" que ganha e as diversas maneiras como os povos indígenas têm se relacionado com as missões. Assim, o conjunto dos artigos que apresenta pode ser escalonado em um contínuo entre conversão e não conversão, entre rejeição e absorção indígena das doutrinas e práticas cristãs. Na perspectiva das congruências, Wright fala de "campo de identidade inter-religioso", que depende de um processo de negociação 
de sentidos e de interpretações por ambas as partes (2004, p. 24); e mesmo de "cosmologias de conversão", nas quais se apreenderiam transformações dos símbolos, cosmologias e/ou aspectos da organização social em formas sincretizadas, mas com firme base nos pressupostos indígenas. O seu foco particular incide sobre a reestruturação do social, a criação ou a elaboração de novas formas considerando a profundidade histórica com que a religião cristã já se estabeleceu nos horizontes indígenas.

Para Paula Montero (op. cit., Introdução e Capítulo I), como a autora mesma afirma, a chave da leitura das relações de traduções múltiplas entre missionários e indígenas - que no seu entender são relações ideológicas que conciliam o global e o local - seria a "teoria da mediação cultural". Segundo esta teoria, a ação missionária carregaria um poder de "produção cultural" nos espaços transculturais e, como conseqüência, menos que transformar as culturas, concorreria para a produção de "configurações culturais específicas". A autora afirma que não se trata de aculturação, pois há disputas simbólicas, negociações e escolhas de parte a parte entre os agentes missionários e indígenas, até que se construam sentidos compartilhados nas zonas de interculturalidade em níveis cada vez mais generalizantes. Todavia, em se tratando de mediações, a atenção se volta para sinais de equivalência, de colaboração, de aliança, de cumplicidade e de consenso sobre os códigos compartilhados.

Alguns estudos nas coletâneas supracitadas enfatizam certa conveniência por parte dos indígenas, ainda que não totalmente consciente ou sob controle, em abraçar uma religião cristã, ou seus cultos e práticas. Esta se manifesta na vantagem percebida em recursos simbólicos que podem dispor para que se situem entre mundos em confronto, ou mesmo para fins pragmáticos na melhora possível nas condições concretas de sobrevivência. Sem ousar qualquer conclusão envolvendo o conjunto dos Terena a partir da fala de Jorge, cabe notar, todavia, que um tipo de manipulação e de uso estratégico da religião entre os Terena aparece na análise de Cardoso de Oliveira (1976). O autor percebeu um uso político das diferentes filiações religiosas, muitas vezes em contraposição ao poder do Sistema de Proteção aos Índios. Moura e Zorzato (2004), por sua vez, falam da apropriação contínua, crescente e estratégica pelos Terena dos espaços e estruturas evangélicos como forma de acesso ao fortalecimento do convívio com a sociedade nacional (2004). Uso semelhante é sublinhado pelo próprio Jorge Terena, quando explica as vantagens em se apropriar do código missionário para se situar no mundo não índio e, para mais tarde, a ele se contrapor. Eu mesma tive oportunidade de ouvir em aldeias terena uma interpretação indígena de certo uso instrumental, 
quando a conversão evangélica é procurada para solucionar problemas como o alcoolismo - razão, como se sabe, não exclusiva dos Terena. Gallois e Grupioni (1999) sublinham a dependência das atividades assistencialistas da missão como motivação para a "conversão", que também questionam. Ademais, esse uso estratégico/instrumental aparece em análises tanto entre os antropólogos que insistem na reprodução das estruturas indígenas na apropriação que fazem da religião cristã, quanto nos que percebem a eficácia do cristianismo em assimilar ou encompassar mundos, pois sempre há uma vantagem presumida em termos de problemas locais, como, por exemplo, o que diz Wright (2004) sobre a conversão ao evangelismo para superar os males da feitiçaria; ou os usos para fins de afirmação ou reconstrução étnica, como em Arruti (2006), neste caso, a partir de uma gramática compartilhada por religiosos e indígenas de fundo "culturalista".

No que diz respeito especificamente à fala de Jorge, percebi na exterioridade com que lida com as crenças cristãs - e apesar da franca adesão terena ao cristianismo, seja o católico ou o evangélico - uma certa relação diferencial com a crença, um distanciamento - que pode se estender, quiçá, ao conjunto dos Terena - que evoca em alguma medida a problematização feita por Viveiros de Castro sobre a conversão indígena. Percebi também na fala de Jorge a manipulação de categorias do mundo ocidental de maneira estratégica e pragmática como já indicara Ramos $(1988,1990)$ para as falas políticas de líderes indígenas. Na fala de Jorge há, portanto, tradução, negociação, escolha. Todavia não há mediação, no sentido que implica de consenso; de outro modo, toda sua fala é estruturada sob o signo do inconciliável e da denúncia da opressão.

Antes de começar a examinar a fala de Jorge, deixo claro que este trabalho não constitui propriamente uma interpretação densa desta fala que exigiria um aprofundamento do conhecimento sobre o universo terena, sobre o empreendimento missionário entre eles e sobre o próprio Jorge. Este trabalho constitui, sobretudo, um exercício específico em cima da fala de Jorge sobre o seu trânsito religioso, com a firme intenção de resguardar a sua perspectiva. Trata-se de um exercício no sentido de apreender, no destrinçar da urdidura de seu texto, as manobras da identidade de um sujeito étnico e a representação de sua situação no mundo. Nisto, creio, há uma ponte para o entendimento de processos mais gerais de produção da diferença na modernidade cultural.

Cabe também ressaltar, desde o início, que a fala de Jorge mostra uma intenção com a qual ele se identifica para os fins que tinha em mente. Todavia, esta intenção não deve ser entendida como uma descrição 
total de si ou de toda a sua experiência, ou como o resumo de sua racionalização para a agência na relação interétnica. Há uma preocupação aqui em, por um lado, não absolutizar o conteúdo da fala de Jorge como se ela fosse a representação de sua essência indígena, terena, híbrida ou o que seja, razão que, ao reverso, ensejaria discussões sobre a autenticidade do discurso indígena. Ademais, o sujeito transeunte negocia e se forma em vários mundos contra a expectativa de que a agência do sujeito étnico siga uma deliberação tranqüila na sua origem indígena, que seria capaz de lhe outorgar uma total "soberania" sobre seu pensamento e ação ${ }^{5}$. O contrário também é verdadeiro: a mensagem explícita de Jorge também deve ser considerada como um discurso de auto-representação que quer se dizer por si só - que é, creio, a razão pela qual Jorge concedeu a entrevista, já que estava certo de que esse seu pensamento seria divulgado.

Tento perceber a diferença indígena na fala de Jorge e creio que ela fica clara no seu hibridismo. Penso que a sua ruptura com o mundo evangélico, bem como as suas noções sobre a espiritualidade indígena, como veremos a seguir, se deve muito ao próprio esquema intelectual e cosmológico cristão e a um tipo de religiosidade de caráter holístico-ecológica moderna ocidental. Isto não deve ser entendido, todavia, conforme a advertência no parágrafo anterior, como uma questão de substituição da lógica indígena pela outra, mas como um processo de tradução na diferença, onde um mesmo significado muda conforme o lugar de onde ele é enunciado. Como também veremos, é na interpretação do próprio Jorge do evangelismo dos Terena que o incomensurável na tradução cultural mais se explicita.

Abordei o discurso de Jorge na confluência entre a etnicidade e a religiosidade, dirigindo-lhe indagações sobre a hermenêutica que fazia acerca de dois universos religiosos em que transitou - o xamanismo e o credo evangélico, bem como sobre a forma como Jorge se subjetiva em função de sua identificação com discursos oriundos de dois sistemas culturais colocados em relação hierárquica. Está em questão também a inscrição da fala do outro no discurso de Jorge e a contra-sentença que dirige ao discurso civilizatório evangélico.

A história que Jorge Terena me contou teve como eixo um aspecto que possivelmente lhe ocupe bastante lugar, já que sua relação com os evangélicos foi longa e intensa, desde a sua "adoção" por missionários americanos, que foi o veículo de sua aventura da sua casa ao internato na casa da missionária na aldeia; da aldeia a São Paulo, de São Paulo aos Estados Unidos e de sua volta ao Brasil e à aldeia. Um itinerário no qual não só a linguagem missionária veio até ele, mas ele se deslocou fisicamente para outro mundo. 


\section{O primeiro tempo da entrevista}

A partir de um único e breve contato telefônico, Jorge concordou solicitamente em conceder-me a entrevista, embora tenha lhe falado rapidamente sobre o que queria: dados para escrever um pequeno trabalho sobre conflito religioso. Creio ser interessante ressaltar este fato de que não houve por parte de Jorge nenhuma resistência, nem uma mínima dúvida quanto a realizar a conversa. Esta concessão não é um fato em princípio surpreendente, mas quis concluir que havia nela, senão um desejo, uma obrigação em fazê-lo, no sentido de uma prática política, homem político que era. É como se Jorge tivesse claro para si a tarefa da exposição de sua fala, enquanto líder indígena. A sua vida como indivíduo, ou a sua história de vida, não se descola da história de sua sociedade de origem e dos povos indígenas no Brasil. O sujeito religioso que procurava era também um sujeito de representação política. A sua auto-representação e a representação de seu povo (e dos índios em geral) - no sentido de auto-imagem - foi articulada politicamente, para o mandato que ocupava como líder indígena. Jorge inicia seu relato voltando à sua infância, momento em que se estabeleceu a sua relação com os missionários da South American Indian Mission ${ }^{6}$, agência que começou a exercer atividades em parte das comunidades terena no início do século XX. Na interpretação deste evento, tão prematuro em sua vida, recorre ao fato recordado, nos termos da criança, para dizer sobre a clivagem entre o mundo indígena e o dos missionários. Mundos recordados como separados, apesar de, como também calculou, setenta por cento dos Terena já terem aderido, naquela época - década de 1960 - ao credo evangélico. Mundos separados, e o evangélico imune à alteridade. Como se verá, esta clivagem estrutura toda a sua enunciação.

Jorge insistiu na violência da entrada dos missionários nas aldeias. $\mathrm{O}$ fato de ter detalhado o tormento de sua experiência infantil alegoriza tanto a vulnerabilidade do outro atingido quanto à intensidade da pressão que o atingiu. A criança indígena tinha dois mundos para comparar e o referencial que encontrava no seu mundo exacerbava a experiência de sofrimento que lhe causavam as atividades missionárias. O primeiro fato que Jorge lembrou na sua narrativa foi a austeridades destas:

A maior parte das crianças da aldeia estudava lá [na escola da missão]. Todo dia tinha sua meia hora de culto. $\mathrm{O}$ diretor fazia a sua pregação para as crianças. E inclusive disciplinava. E chegava a ter palmatória. Lembro que alguns alunos apanharam mesmo com pedaço de tábua na frente de todos os outros alunos, dentro da igreja. Antes de terminar o culto, eles chamavam as pessoas que eram culpadas de alguma coisa 
e ali eles eram castigados na frente de todo mundo.

Se houvesse alguém que tinha sido acusado de ter feito alguma coisa errada. Se era mentira, era lavagem da boca com sabão e água; ou então, se era não ter feito o dever de casa, por exemplo, era ficar no canto da sala com pedras ou milho no chão para você ficar de joelhos ali até a hora de eles decidirem quando você poderia sair ou levantar.

Muitas vezes, na frente de todo mundo, o pessoal apanhava mesmo. Muitas vezes os alunos não entendiam porque isto estava acontecendo. Isto ficou bem claro uma vez que um aluno, um amigo nosso que era muito brincalhão mesmo, um cara de bom humor, chegou lá na frente de todo mundo, ele teve que apanhar. Aí o diretor perguntou para ele: 'aí, gostou, você quer mais?' Ele ficou meio rindo. Aí todo mundo ria dele. E dava nele de novo. Na verdade, acho que ele não estava entendendo bem o que estava significando toda esta coisa lá para eles. Então, a gente tinha que se submeter a este tipo de disciplina dentro da escola.

Jorge prosseguiu contando a sua experiência de "internato", que começou aos sete anos de idade, quando passou a morar na casa de uma das missionárias. Ali, o menino Jorge sentiu-se um prisioneiro (sic), fugiu várias vezes para aldeia sendo sempre resgatado pela missionária. $\mathrm{O}$ relato alterna-se entre as fugas e retorno, matizando a comparação entre os dois mundos.

O meu tio aceitou que eu fosse morar com a missionária [Jorge morava com o tio materno, pois sua mãe, viúva, havia se mudado para a cidade de Aquidauana, onde trabalhava].

Dentro da casa dela tinha todas as regras: você tinha que tomar banho na hora certa, dormir na hora certa, comer na hora certa. As crianças não gostam de dormir à tarde, querem ficar livres, brincando por aí. Depois de acordar tinha que fazer o dever. Depois do dever, você tinha uma hora ou meia para jogar bola. Depois de certa hora você voltava para jantar. Depois, antes de dormir, você fazia um pouco de dever de novo.

Eu não me senti muito bem com estas regras. Além, no final de semana, você tinha que passar um tempo na igreja. Sexta-feira à noite, tinha alguma coisa lá para os adultos e as crianças também tinham que ir. Ou sábado à tarde, também tinha que estar lá. Domingo, por exemplo, não podia jogar bola porque era dia sagrado, mas tinha que ir à igreja. E sabe que no domingo tem a escola dominical. Depois tem o culto. Depois, às cinco horas, tem o culto para as crianças, palestras para os jovens. À noite tem o culto para todo mundo. Então eu tinha que conviver com tudo isso. E eu me sentia realmente um prisioneiro, porque na aldeia você não tinha todas essa regras de convivência. Nem tampouco para você aprender esta questão da espiritualidade, você aprendia vendo a coisa acontecer ali na sua frente, quando acontecia. 
Ou então alguém falando para você o que estava acontecendo, explicando para você. Na igreja não, qualquer um, sendo católico ou não, você tem que ir lá na igreja, para você ouvir o pastor e tal. Mas quando você faz a pajelança, não é todo dia e não é todo final de semana. Então, quando você assiste uma pajelança, você está ali e você tem que reverenciar também a pajelança. Mas você sempre tem algum adulto te explicando o que está acontecendo, o que vai acontecer, tudo isso. Então, de antemão, você já sabe o que vai acontecer. Agora, você vai à igreja, você não sabe por que você foi e como é que você vai sair de lá, ou que resultado vai ter o culto. Na pajelança você sabe se o pajé vai dar conta de resolver o problema ou não.

E outras coisas, a gente não tinha esta coisa de que só porque é domingo você não pode fazer tal coisa, você não pode pescar etc. Esta questão de você só comer peixe na Semana Santa, por exemplo, que vem dos evangélicos ou dos católicos. Eu até hoje, para mim eu não vejo por que. Estes tabus que a gente não tem dentro da aldeia. Agora, existem sim outros tabus que estão ligados diretamente à religião também, ou à espiritualidade. Tem certas coisas que não se pode comer, ou tem certas coisas que são proibidas o homem ou a mulher comer, porque isto tem um significado espiritual para a mulher ou para o homem. Mas também não é uma coisa constante não, são certas épocas que se come ou não se come alguma coisa assim.

[Depois da primeira fuga] começou uma fase de disciplina, porque eu realmente me rebelava com os horários. Tinha dias que eu realmente não dormia. Não queria dormir. Ficava dentro de casa fazendo outras coisas, menos dormir. E aí a missionária me colocava de castigo por causa disso. Muitas vezes até de ficar sem jantar, por exemplo, por não ter dormido. Ou então, se eu não dava conta de terminar o meu dever para o outro dia, então muitas vezes ficava sem o almoço. E aquilo já começou a me irritar novamente.

Mas só que ela achava que disciplinando a gente, certas coisas a gente aprenderia, não somente a lhe obedecer, mas a obedecer às regras também. Bom, eu cheguei a pensar uma vez que as regras realmente existem na vida de qualquer um, por mais que sejam desordenadas estas regras, elas existem sim. Mesmo na aldeia, você tem hora para dormir, você tem hora para levantar, você tem hora para caçar, para pescar, tudo isto, quer dizer, também não é tudo brincadeira. Mas é um calendário que me parece assim que cada um faz o seu horário, o seu calendário de atividades, conforme a sua necessidade, não conforme você acha que a pessoa deve ter. Então comecei realmente entender o que é a lavagem cerebral, tudo isso. Eu tinha que ir à igreja quando tinha culto, eu tinha que participar das atividades da igreja quando tinha. E por sinal você era colocado no castigo.

Eu continuei com ela, mas aí veio uma segunda fuga para a aldeia. Aí demorou um pouco, e meu tio pensou algumas vezes, inclusive eu até tinha passado por experiências de realmente apanhar da própria 
missionária por indisciplina. E eu tinha falado isto com o meu tio e aí ele ficou meio preocupado. Ele então me segurou por um mês mais ou menos. E a missionária toda semana ia lá querendo que eu voltasse de novo. Aí o meu tio decidiu ir para uma fazenda e eu queria ir com ele. Ele achava que eu era muito pequeno para ir trabalhar com ele na fazenda- eu tinha uns nove anos mais ou menos. 'Você vai voltar para a missionária, fica lá'. Tive que voltar.

Mas foi uma tortura, inclusive vários outros índios passaram por ali; eles não ficaram, foram embora, os pais não deixaram voltar. Só eu que fui sendo empurrado.

A comparação entre a vida na aldeia e a rotina na missão estrutura este trecho de sua fala. Quando compara, embora esteja recordando o passado, os tempos verbais que usa fazem confluir passado e presente. A interpretação não é daquele tempo. Por exemplo, Jorge diz: "Agora, você vai à igreja, vocênão sabe por que você foi e como é que você vai sair de lá, ou que resultado vai ter o culto". Ou, "Esta questão de você só comer peixe na Semana Santa, por exemplo, que vem dos evangélicos ou dos católicos. Eu até hoje, para mim eu não vejo por quê. Estes tabus que a gente não tem dentro da aldeia".

Jorge mostra a falta de sentido em freqüentar o ritual cristão. Primeiro, por ser uma imposição alienígena. Mas uma imposição contra a qual não se rebela. Por que não? Jorge não fala desta rebelião. O seu recurso é comparar as religiosidades. A indígena faz sentido não só porque é própria, mas porque encontra ali uma sensatez que escapa ao evangélico. Jorge prefere deslindar-lhes as suas incoerências. Assim preserva uma integridade por desautorizar as práticas equivocadas da religião do outro que vem para dominar por meio dela. Jorge contrapõe "espiritualidade" e religião, a primeira é como chama a religiosidade indígena, e não se confunde com a segunda, que é dos brancos, que é violenta e "burocrática". Nas suas palavras, a religião dos evangélicos não faz sentido não só porque é imposta, não faz sentido mesmo referenciada a si. As práticas ascéticas evangélicas nunca poderiam se construir na forma ideal de vida do ser humano. E não precisou ler a célebre análise de Max Weber da ética que pregava o pecado principal da perda de tempo, o perigo do relaxamento, do ócio e do prazer, o interdito da liberdade. Na representação de Jorge, o mundo indígena expressa justamente o que a religião evangélica teve que abrir mão para se constituir.

Num trecho seguinte da entrevista, Jorge vai enfatizar a importância percebida pelo empreendimento colonizador em atingir a espinha dorsal que sustenta o mundo indígena: as suas próprias crenças religiosas. 
Eu já ia fazer onze anos de idade e eu fui trabalhar com o meu tio na fazenda...

Era melhor porque você ficava o dia inteiro trabalhando, andando a cavalo, atrás dos bichos, dos bois, dos bezerros. Era mais livre.

Eu tive muita influência do meu tio. Porque chegou um certo tempo que eu estava com ele, ele era um pajé também. E ele estava tentando me ensinar a ser pajé. O tempo que eu passei trabalhando com ele na fazenda, ele tentava me ensinar as coisas. E ali, como a gente estava longe das influências 'carnais' vamos dizer da cidade, tudo isto; que nós estávamos no meio do mato, a gente via e sentia a força, a força divina; a presença do ser criador ali perto da gente e tudo. Então ele me dizia que o mundo é regido por um ser maior do que a gente, que entende a gente, e que para a gente chegar a esse ser existe um espírito, ele falava assim. E esse espírito é que vem em mim, ele falava. Então o trabalho que eu faço é trabalho de Deus, ele falava assim para mim. Quer dizer, o espírito bom incorporava nele e ali ele fazia as curas dele ou o que tinha que fazer. Então isso para mim marcou bastante, porque eu presenciei coisas acontecendo.

[...] Ele inclusive até chegou a ser crente depois, este meu tio. Mas depois também viu que não era por aí também e também largou, desistiu. Existem certas contradições na própria religião, vamos dizer, de pregar a paz, ou pregar a bondade, ou pregar a fraternidade, mas que ao mesmo tempo eles reprimem a sua vida de paz, de fraternidade. Isto está bem claro na nossa história, no início do descobrimento do Brasil, que os próprios jesuítas se juntaram com as forças portuguesas, com o exército português, para matar os índios, para roubar as mulheres, para roubar as crianças, para deixar as crianças longe da aldeia deles, longe das suas crenças, e inculcar a crença católica nestas crianças. Porque eles queriam mudar os índios de religião. Por que? Porque isto era uma religião muito forte e que tinha que ser quebrada. A igreja católica, hoje nós não vemos, por exemplo, a história oficial das derrotas com os índios, as guerras aqui do litoral. Por quê? Porque eles não queriam mostrar a vergonha que eles passaram por serem derrotados pelos índios. Que a igreja veio salvar? Vieram é matar os índios. E a primeira coisa era atacar a religião deles. Mas graças a Deus eu acho que esta resistência que nós tivemos, não só uma resistência física e cultural, mas... (Jorge se emocionou neste momento).

Esta resistência espiritual que eu acho que é o que mantém o nosso povo. E como dizia o velho índio Seattle, que o nosso Deus é o mesmo Deus dos brancos. As andorinhas, os pássaros que voam, são cuidados pelo mesmo Deus. Esse Deus cuida tanto do branco como do índio vermelho. Inclusive a terra é de Deus, então, se alguém fizer algum dano a terra, ele está desafiando o criador. Então esta espiritualidade que nós temos tem mantido a sobrevivência de cada povo. E isto é muito forte. Porque você vê, no nordeste por exemplo. Os índios 
Potiguaras foram praticamente exterminados e foram deixados ali, num local chamado Baía da Traição. Mas restou um remanescente ali e eles, apesar de hoje perderem a sua língua, eles têm uma espiritualidade e esta espiritualidade é que os mantém vivos ate hoje. Os índios Fulni-ô, que foram praticamente também exterminados, estão aí ainda sobrevivendo. Os índios Pataxós estão sobrevivendo por quê? Por causa da espiritualidade deste povo que os mantém juntos. Mas as igrejas, as missões chegaram ao Brasil justamente querendo quebrar isto. Tanto católicos quanto evangélicos. Porque isto é o elo dentro das comunidades, é o elo entre as comunidades e o ser espiritual.

Eu acho que a espiritualidade que os índios têm e a religiosidade do mundo, de uma certa forma buscam o mesmo ser criador, mas com formas diferentes. No meu ponto de vista, talvez até um ponto de vista holístico quanto a isso, eu acho que nós índios temos o caminho mais puro para chegar a esse Deus. Eu sigo a minha espiritualidade indígena. E um dia todo mundo vai chegar lá. Vai chegar lá.

As pessoas vivem saltando de uma religião para outra buscando aquela espiritualidade que tinha perdido já há muito tempo e que os índios ainda detêm.

Não é fato incomum que a representação indígena de sua resistência e de sua identidade venha a dever à sua "unidade religiosa" e que o discurso da militância derive suas categorias do discurso religioso. $\mathrm{O}$ uso de uma religiosidade por assim dizer pan-indígena para se autodescrever talvez de deva ao fato de a referência terena estar muito marcada por motivos cristãos.

Outro aspecto importante que aflora de sua fala é o fato de alguém que foi evangélico durante boa parte de sua vida não enunciar nenhum vínculo com esta religiosidade. Jorge freqüentou continuamente cultos evangélicos, ouviu pregações, enfim, supostamente experimentou uma imersão na cosmologia cristã. Sua fala é notavelmente rebelde com relação a tudo referente ao mundo evangélico. Não encontra nenhum sentido lá. A religião evangélica não constitui objeto do seu mais mínimo desejo.

Jorge lamenta a atividade missionária: “É uma responsabilidade muito grande querer mudar a espiritualidade de uma pessoa. É querer mudar o destino, a alma, o ser de uma pessoa. Pregar outro plano espiritual que os índios não entendem é muito grave. Mais tarde, tem que prestar conta com Deus". O Deus que é "o mesmo ser que todos buscam".

Diria que Jorge, como sujeito da sua representação, revela um retrato seu, de seu povo e dos índios em geral através da resistência indígena devida à espiritualidade (com uma base na fala rebelde, no sentido de oposição). Ao se rebelar, Jorge pôde postar-se como sujeito, pôde abandonar o credo e reafirmar-se. Ademais, descreve-se como terena na medi- 
da em que se subjetivou de uma determinada maneira diante desta espiritualidade (chamo a atenção agora, mas reservo para um momento seguinte a distinção entre o posicionamento de Jorge perante os evangélicos e à adesão evangélica dos Terena). É a espiritualidade que cria um sentido de comunidade e da diferença. Os índios têm o "caminho mais puro" para atingir a necessidade humana básica da religião. Os índios têm, nisto, um papel "civilizatório": "um dia todo mundo vai chegar lá".

Como sujeito da representação política indígena, fala em nome dos índios em geral. O que demanda esta representação é a perpetuação dos povos indígenas, com pilar na sua espiritualidade. Reivindica também outra história dos povos indígenas que não a que os brancos contaram.

Em outro trecho da entrevista Jorge, vai dizer que tem uma dívida (sic) para com os povos indígenas, por causa de suas conquistas pessoais em termos de educação e projeção pública.

Eu sempre tive esta noção, esta idéia de que eu fui para fora justamente para ter o conhecimento para defender o meu povo. E quando digo o meu povo não é somente Terena, mas são os índios como um todo. Então eu tinha uma dívida com os povos indígenas de ajudá-los a se defenderem do que eles não conhecem, de esclarecer para eles o que são as coisas aqui.

Como se sabe, o acesso à educação formal figura é item importante da pauta de reivindicação indígena, hoje, no país, e o sentido desta conquista está na fala de Jorge. Está claro o entendimento da educação escolar como um instrumento que é do outro, mas que é indispensável para que possam dizer-se, para que possam ser sujeitos no confronto intercultural com os não índios. Isso para além da preocupação com assimilação das ideologias veiculadas pela escola, que parecem ser consideradas pelos indígenas como outras cosmologias, i.é, seria idealmente possível manter uma autonomia perante elas, um distanciamento, e operar escolhas e incorporações julgadas necessárias.

\section{A inscrição da fala do outro}

Aos quatorze anos de idade, Jorge reencontra a missionária, que o convida a morar com ela em São Paulo, onde teria a oportunidade de dar continuidade à sua formação escolar.

Eu fiquei pensando, depois da conversa com ela. Quando eu comecei a estudar, uma das coisas que eu queria era aprender tudo o que estes missionários fazem e depois dar umas porradas neles para não aproveitar do povo. Porque eles sempre usavam os índios para plantar 
coisas para eles, como mandioca, milho, e não davam nada para o pessoal capinar, limpar a roça. E quando davam alguma coisa eram usadas, quase rasgando. Então, eles aproveitavam muito do pessoal.

Era aquela coisa, porque nós somos irmãos, somos cristãos, evangélicos, então nós temos que ajudar uns aos outros... Não questionavam esta atitude. Para eles, eles não estavam sendo usados, estavam ajudando os missionários.

Mas depois que você começa a falar para eles: o tempo que você está gastando aqui, você poderia estar gastando na sua roça lá. Quem é que está fazendo o trabalho lá na sua roça? Quer dizer, você não vai se atrasar lá para atender a necessidade da outra pessoa aqui, não ganhando nada? O que você vai levar da roça aqui? Nada. Fica tudo para eles. Então eu fiquei pensando.

Jorge ressalta a posição subalterna dos índios em relação aos missionários e se coloca em separado, como consciente de uma exploração que os próprios índios não questionavam. Enfatiza a razão de seguir para o mundo dos brancos:

Aí eu comecei a realmente querer aprender mais as coisas, tive mais interesse pelos estudos e tal. Quando eu chegava na casa onde a missionária estava morando, porque não era dela, era de uma outra família, também eram americanos. Chegava lá à noite, depois da escola, eles começavam a falar inglês entre eles. Aí eu ficava escutando e tal. Aí eu pensei, um dia eu vou aprender a língua deles para ver se eles vão ficar falando inglês aqui na minha frente.

A possibilidade de falar, de ser sujeito: era necessário lançar mão da gramática do outro para inscrever a sua própria fala. Jorge ambicionou assimilá-la como um projeto político. Jorge também fala, entretanto, que a disciplina que tanto abominava lhe foi útil para sobreviver na sua experiência de trânsito. Ao mesmo tempo em que destaca o caráter instrumental das coisas do outro que foi buscar para se defender deste próprio outro, a estrutura para viver neste mundo (e aqui já é um mundo cujos limites perpassam os dois lados, não há só o mundo indígena), esta estrutura tinha que vir do outro, não do seu mundo.

Mas quando eu lembro assim da experiência, mais tarde foi válido sim, porque quando eu entrei na universidade eu tinha que ter um horário disciplinado para fazer as coisas, porque senão não dava conta. E aí, de uma certa forma, eu me arrependi: se eu tivesse obedecido lá no início, talvez eu não estaria sofrendo tanto hoje; indisciplinado que era, por mais que tenha feito um calendário de horários. Porque na universidade, além do trabalho, tinha o estudo, e tinha todos os trabalhos para fazer, trabalhos de pesquisa, tudo isso. E que leva tempo, se você não for disciplinado, você não consegue fazer nada. Mas olhando para trás, quando eu estava na universidade, isto me serviu sim de 
alguma forma para me disciplinar a fazer várias coisas. E eu acho que para até conquistar o espaço que eu tenho conquistado até hoje, quanto mais pelo fato de ter disciplina mesmo. Mas a disciplina eu acho que tem que vir como parte da necessidade da sua própria vida, e não imposta.

Por um lado, os indígenas são obrigados a ocupar o lugar de outro que lhe é atribuído pelo missionário. Jorge certamente teve que lidar com a visão missionária do outro/índio - certamente uma das fontes de sua rebeldia. Por outro, diria que a incorporação da disciplina por Jorge é híbrida, porque ele é disciplinado (evangélico) e rebelde (outro). Ela não é capaz de fazer a fala do 'outro' Jorge indistinguível da gramática missionária. Voltarei a esta discussão mais vezes no decorrer do texto, pois ela se completa com outros elementos que ainda virão.

\section{Jorge, um estrangeiro}

Para melhor aprender o inglês, Jorge fez uma primeira viagem aos Estados Unidos, num programa de intercâmbio oferecido pela escola de inglês que freqüentava em São Paulo, na adolescência. Ao retornar, continuou seus estudos e começou a planejar seu futuro. O curso dos acontecimentos acabou levando-o de volta aos Estados Unidos, para a universidade. Conseguiu uma vaga na Universidade de Maryland (local de origem da missionária). Mas a missionária com quem vivia exigiu-lhe que fizesse pelo menos um ano de teologia e, assim, Jorge foi antes para uma universidade evangélica, onde acabou fazendo os quatro anos de college: "fiz uma parte de filosofia, uma parte de pedagogia e uma parte de sociologia. Mais de pedagogia que sociologia. Inclusive, no meu diploma, diz filosofia e pedagogia. Quer dizer, se eu quisesse dar aulas hoje, eu poderia fazê-lo". Após estes quatro anos, foi para a Universidade de Maryland fazer o mestrado. Ao todo, foram sete anos.

Mas nesses quatro anos que eu passei na universidade evangélica, foram anos bem difíceis para mim também. Porque, apesar de ser uma escola evangélica, eu era visto como um estrangeiro dentro da universidade tomando lugar de um americano. Acho que havia aquela frase go home yankee. Então, eu senti isto muito na pele. Aqui o go home yankee era para eles qualquer estrangeiro. Então, quando eles diziam para mim 'vá embora, estrangeiro', a gente sentia muito isto na pele.

Esses alunos preconceituosos realmente faziam coisas para fazer a gente desistir mesmo. Não era só comigo, com os outros estrangeiros ali eles faziam a mesma coisa. Aquilo, de uma certa forma, começou a me revoltar, porque eu achava que eu estava num país cristão, 
predominantemente cristão, numa universidade evangélica, e passar por tudo isso. E aí eu comecei a realmente questionar se eu sigo ou não este lado do cristianismo. Porque eu realmente comecei a pensar de que um dia eu voltaria para ser um missionário entre os índios e tal.

Porque eu via essas pessoas, esses americanos indo lá para as aldeias, conhecer novas aldeias, e trabalhando com eles. Isto para mim era bonito. Mas não era esta questão de evangelizar não. Mas mais tarde, quando entrei no segundo grau, comecei a pensar um pouco nesta questão, talvez seria a maneira de ajudar o meu povo e tal. Mas aí, mais tarde, quando cheguei na universidade e vi a contradição, aí acabou com essa minha visão. Por quê? Porque os evangélicos pregam uma coisa e fazem outra.

Em outra parte da entrevista, Jorge afirmou que era pior ser estrangeiro nos Estados Unidos, do que ser "bugre" no Mato Grosso de Sul, o preconceito era pior. A contradição dos evangélicos foi o que o fez aprofundar o seu questionamento. $\mathrm{O}$ doutrinamento na aldeia, a tortura a que fora submetido em criança, a exploração dos Terena pelos missionários, tudo formava uma seqüência, certamente, capaz de lhe proporcionar certo questionamento, mas ele ainda tinha pensado em se tornar missionário. Foi o contato com os evangélicos nos Estados Unidos o que o fez desistir da igreja. "Porque os evangélicos pregam uma coisa e fazem outra". Jorge exigia a coerência, clara em princípio aos protestantes, mas que eles não podiam cumprir. Usa a própria moralidade protestante para questionar a sua prática (dos protestantes). E pôde, assim, usar o discurso do outro para declarar o seu desejo. A sua história sui generis, de alguém sozinho no meio da alteridade, lhe garante uma fala de indivíduo, e se poderia supor que Jorge também usou o individualismo protestante como instrumento.

A faculdade me fez questionar toda esta pregação. Tudo, nas aulas, na prática, no que lia.

Eu tentando conversar com os professores, eu sozinho discutindo com os professores. Porque eu não podia levantar esta discussão na sala de aula, porque todo mundo ali engolia o que estava ouvindo. Eu não conseguia. Então, depois das aulas marcava uma hora para conversar com os professores. Eles achavam que eu estava ficando rebelde já, por não crer nas escrituras e tal. Eu falei: então vamos chegar num acordo aqui. Você vai à igreja por quê? Por que você vai à igreja? Eu falei, até então eu ia à igreja porque senão as pessoas me viam como desertor da igreja, ou como pecador, ou como ruim, porque eles iam falar "ah, o irmão Jorge já não está mais indo na igreja, deve ter muitos problemas". Com certeza eu tenho problema. Então eu falei, com certeza eu estou indo na igreja por influência dos outros, não porque eu quero.

E então a própria missionária viu quando eu comecei a não participar 
mais da igreja. Decidi não ir mais. E ela começou a me pressionar, porque senão Deus ia me castigar se eu não voltasse, ou que eu ia ser um mau testemunho para as outras pessoas, não sei o que. Eu falei: olha, acontece o seguinte, que eu venho vivendo a minha vida para agradar outras pessoas. Eu não tenho sido feliz na minha vida.

A certa altura da entrevista perguntei a Jorge se, dada a intensidade e a duração de sua imersão no mundo evangélico, ele não tinha operado nenhum investimento afetivo, de desejo, com relação às crenças evangélicas. E Jorge respondeu que nada o atraía naquela religião e se posiciona como outro entre universos clivados.

Nada, nada. Porque isto eu já sentia muito mais com o meu pessoal, que tinha a própria espiritualidade dentro do pajé, dentro do espírito que sempre nos era na aldeia. E quando eu fazia as minhas caminhadas, por exemplo, no parque que eu tinha ali, eu sentia esta presença muito mais forte. Porque para mim eu estava perto da natureza. Não era dentro da igreja que eu sentia isto não. $\mathrm{E}$ eu perguntava para os professores o seguinte: você dá o seu dízimo por quê? Ah, porque se você não der o pastor vai dizer " ah, o fulano ali está pecando, não está dando o dízimo". Você vê que você não está fazendo as coisas de coração, você está fazendo porque os outros querem que você faça? Eu falei, isto é uma farsa, isto é uma mentira. Até quando a gente vai ficar mentindo para a gente e dizer "ah, eu vivo bem sim". Você vive bem à custa dos outros te mandarem fazer as coisas? Quer dizer, eu estou me reprimindo em fazer as coisas que eu quero, porque os outros me mandam fazer outra coisa? Aí eu falei, esta é uma vida de mentira que a gente leva. Aí perguntava para eles o seguinte: se você faltar um domingo o pastor vai perceber a sua falta. Vai perguntar para você: "irmã, nós sentimos a sua falta no domingo, o que foi?" Aí você vai inventar um monte de história, "ah, porque o meu pneu furou, porque eu tive que fazer uma emergência, ah..." Porque você não chega e fala: "olha pastor, eu não quis ir porque tinha um jogo de futebol, preferi ficar em casa e assistir o jogo de futebol do que à igreja". Pronto, acabou. Por que ele não pode falar a verdade? Tem que mentir. Ou então o pastor chega e pergunta para você: "irmã, como é que você está se sentindo, você está bem?". "Ah, pastor, graças a Deus eu estou me sentindo muito bem, recebido muitas bênçãos", enquanto que você por dentro está passando por problemas. Lá fora, lá na sua casa, no trabalho, você está enfrentando problemas. Mas você vai chegar e falar isto para o pastor? E nem o pastor vai chegar e ouvir, ele não vai sentar, dizer: "irmã, vamos ali, vamos sentar e vamos conversar sobre este problema, vamos ver o que a gente pode fazer". Não faz isto. É um pro forma dizer "ah, como vai?" e você dizer "ah, tudo bem" quando você está $\operatorname{com} n$ problemas na cabeça. Está mentindo!

Aquela religião é uma forma de controlar o comportamento das pessoas e só se pode viver sob estas condições se se tiver um pacto com a 
mentira - aqui Jorge estende a afirmação para além da condição do indígena colonizado, que é forçado a fazer aquilo que não deseja; os brancos que vivem sobre estas prerrogativas principalmente também o são. É uma crítica contumaz ao outro, a partir do que se contrapõe ao discurso hegemônico da inferiorização do mundo indígena. Aquele é um mundo de mentira. O ser indígena traz uma lição. Jorge é alguém que transitou intimamente entre vários mundos. Mas como se constrói diante desta experiência? É como se dissesse, eu passei por tudo isto, recolhi o que me interessava, mas não mudei. E invoca o mundo terena.

\section{A volta para o Brasil}

E quando eu voltei para o Brasil, todo mundo se assustou comigo achando que eu ia vir de lá formado pastor, mais não sei o que. E aí eu chego aqui e não é nada disto.

Os Terena Tinham esta expectativa, a própria missão também tinha esta expectativa.

Os Terena desejavam que eu voltasse como pastor.

Quando eu fui para lá surgiram vários pastores terena. Inclusive eles faziam escolas de teologia aqui, estas escolas de teologia rápida no Brasil, e alguns deles são missionários aí nas outras aldeias. Tem bastante lá no Xingu, tem bastante Terena para lá. Eles estão para tudo que é lado, Yawalapití, lá no Diauarum, no Kuikúro. Isto já tem uns dez anos já. O pessoal vem andando. Quando eu voltei para o Brasil em 1982, já tinha índios Terena indo para outros lugares, indo para os Xavante, mas eles não ficavam, iam e voltavam. Agora nestes últimos dez anos é que eles estão indo para morar junto com as pessoas na aldeia.

O espanto dos Terena quanto ao abandono das práticas e das crenças evangélicas é explicado pelo fato de que muitos Terena eram evangélicos, mesmo missionários, enquanto que a atitude de Jorge foi exclusivamente sua.

Hoje a igreja na aldeia é composta só por Terena. Pastor terena. Congregação terena. Questionar assim diretamente, eu fui o único. Porque os outros até hoje têm vergonha de fazer certas coisas que eles fazem na minha frente, mas na igreja eles não fazem, ou quando estiver com um irmão da igreja, não faz. Tomar cerveja, por exemplo.

Porque eles mesmos não acreditam, mas eles não têm coragem de chegar e peitar a coisa. Pelo próprio medo de ser discriminado dentro da comunidade. Ou discriminado dentro da família.

Então, quando eu cheguei, enfrentei a coisa, porque o pessoal achava que eu deveria andar na igreja, e de repente quando me viram eu esta- 
va andando nos bares, eles ficaram assustados: 'o que é isto, está desviado, rejeitou a igreja, o que foi?' e tal.

Eu disse para eles o seguinte olha - e como falo para qualquer pastor que venha me falar - é o seguinte: quem é que me diz que se eu estiver entre quatro paredes e que se chama igreja, que eu vou me sentir mais espiritual? E que eu vou me sentir mais perto do Criador? Ninguém me assegura isto. Isto é uma coisa interna minha.

A comunidade me cobra até hoje. Então quando eu voltei dos Estados Unidos eu tive de certa forma que enfrentar uma expectativa que o meu próprio povo tinha, que era justamente que eles achavam que eu ia continuar evangélico, porque eles achavam que as outras pessoas que saíram comigo ainda continuaram evangélicos e por que eu também não podia continuar evangélico?

Inclusive eu trouxe minha ex-esposa para cá [uma americana evangélica, com quem teve um filho], para conhecer a aldeia, conheceram o meu filho e tal. E eu acho que isso deu maior expectativa para eles de que eu ia continuar no evangelismo. Mas quando eu voltei e quando eles viram que eu voltei mudado, eles ficaram assustados. Hoje eles me respeitam e respeitam o meu ponto de vista porque eles sabem também pelo que eles passaram e sabem por que eles estão passando. Mas eles não têm a mesma coragem que eu tenho, de chegar e dizer: basta. Então demorei muito, por exemplo, a convencer os meus colegas que cresceram junto comigo e que foram evangélicos por muito tempo a pensar da forma que eu estou pensando hoje, mas eles não acreditam totalmente, mas já estão a caminho.

Mas eles ouviam muito o que eu tinha dizer como até hoje ouvem. Eles pensam, "saiu, é estudado, tem muito conhecimento, então sabe o que está falando". Alguns jovens decidiram assumir então, mas continuam a ir à igreja, não largam da igreja.

\section{Os missionários terena}

A própria igreja evangélica está questionando esta ingerência ou esta imposição, vamos dizer. Os próprios evangélicos hoje já estão dizendo as práticas culturais não tem nada a ver com o que nós estamos querendo pregar, as práticas culturais têm que continuar, para fortalecer a comunidade. Com isto mudam certas imposições.

"Proteger as comunidades" é um significante importante hoje e compartilhado por índios e missões. Uma vez a missão civilizadora disse aos índios que eles deveriam transformar-se, deixar o seu mundo primitivo e abraçar a civilização. Agora dizem que eles devem manter suas culturas. É significante que circula em diferentes foros de reivindicação e agências de apoio aos indígenas, fazendo coro ao discurso plasmador do 
multiculturalismo, que articula internacionalmente projetos universalistas de identidade, e tem por trás uma visão monolítica da identidade e do interesse dos grupos.

Os missionários terena vão agora com esta perspectiva de ter que manter a cultura. Vamos manter as nossas culturas, mas ao mesmo tempo vamos obedecer ao nosso Criador. Agora isso está sendo uma lição para os missionários terena, porque várias comunidades para onde eles vão têm uma visão diferente da própria criação do mundo da própria condução da espiritualidade, que de uma certa forma não bate com o que eles crêem que é o do cristianismo. Aí ele tem que repensar totalmente como ele vai agir lá dentro da comunidade, para ensinar o povo. Então já ouvi muitos terena que foram, e não deram conta, voltaram. Para justamente não impor alguma coisa nos outro índios. Pelo menos nisso eles tiveram senso, de não continuar lá querendo impor as coisas.

Como entender, a partir de sua própria fala, a saída individual de Jorge? A sua experiência pessoal certamente lhe trouxe muitos obstáculos a enfrentar: a falta dos pais e as dificuldades do tio fizeram com que fosse "empurrado" para o mundo evangélico; o adolescente na cidade grande, com medo de andar nas ruas, com medo das pessoas desconhecidas com quem cruzava e de quem se desviava, com dificuldade em falar o português; o estrangeiro enfrentando a xenofobia. E, sobretudo, o índio catequizado só, entre os missionários americanos.

Por ser oriundo de uma cultura em que o vínculo local, os liames de parentesco e comunitários são muito fortes e importantes, com regras de convivência opostas às do mundo individualista, pelo tempo e intensidade de sua imersão no mundo do outro, pela solidão da sua experiência, Jorge estava mais ameaçado de perder o seu mundo. Melhor dizendo, talvez tenha se submetido mais ao limite desta situação de imposição do outro, enquanto os Terena, nas aldeias, embora evangélicos, não. Sozinho, o impacto da sua representação pelo outro o atingiu sem a retaguarda dos laços comunitários. Nas aldeias, a comunidade e seus processos - religiosos, políticos, morais etc - asseguram uma dinâmica mais negociada, além de um processamento contínuo, local e contingente daquilo que vem de fora.

Não se pode separar as circunstâncias da construção de Jorge como sujeito. Primeiro, ele foi obrigado, pelas contingências que cercaram a sua infância, a seguir um destino que lhe causava repulsa. Quando jovem, teve consciência da utilidade de seu sacrifício. O sacrifício, a disciplina, são elementos do mundo cristão e o caminho para o seu percurso dentro dele. Mas, na sua visão, são apenas instrumentos. 
Na sua representação deste seu percurso, ele carregou consigo, como uma carapaça impermeável, mas aderente, uma base ou uma consciência terena. Creio que Jorge diz que é possível incluir as produções do outro, permanecendo outro, reconhecendo-se em sua diferença. A sua teoria é de que não há assimilação. Ele inclui conhecimentos, bens culturais dos brancos, mas numa inclusão que é agregação. Tudo apenas se agrega à sua base terena.

Mas como pensa esta base? Um indicador dela pode estar numa cronologia de seu povo, que retrata, e que não é a ocidental. Está implícita, na fala de Jorge sobre os Terena e sobre os índios em geral, uma idéia de tempo que os retira da correlação objetiva, cientifizante, das coordenadas espaciais e temporais ocidentais. Há uma simultaneidade, uma permanência permitida pelo tempo mítico. Esse tempo permanece e seu alicerce é a espiritualidade indígena: a espiritualidade terena, potiguara, pataxó, fulni-ô, seattle.

Na época de sua infância, os Terena já contavam com algumas décadas da presença missionária, protestante ou católica, que inclusive era motivo para a formação ou fortalecimento de facções dentro das aldeias. Já estavam cercados por vilas, cidades, fazendas, estrada de ferro, já eram trabalhadores rurais, prestadores de serviços nas cidades vizinhas etc, estavam em processo de assimilação (Cardoso de Oliveira, op. cit.). No entanto, Jorge recorda um mundo terena "puro", imune a essas contingências. Cria-se aqui uma crise de interpretação entre a representação nativa e a representação objetiva do antropólogo.

\section{O hibridismo de Jorge}

Jorge contou-me também sobre o cenário atual de trânsitos religiosos dentro das comunidades terena. Atualmente, os Terena adeptos da doutrina evangélica ortodoxa vêm perdendo a hegemonia que tiveram no passado.

...as próprias igrejas começaram a aumentar nos Terena. O número de diferentes igrejas. Porque antigamente se achava que era só essa igreja dos missionários, a igreja ortodoxa. Mas aí de repente chegou a Assembléia de Deus, chegou o reverendo Moon, chegaram quinze diferentes igrejas lá. Aí os ortodoxos se juntaram e criaram a UNIEDAS (União das Igrejas Evangélicas da América do Sul). América do Sul porque é a visão dos missionários da South American.

Quando já havíamos encerrado a entrevista, Jorge contoume, enquanto nos despedíamos, sobre os pajés que estão "retornando". Citou-me o caso de dois jovens em sua comunidade, um deles muito 
procurado, por sua qualidade de vidente (sic), por pessoas vindas de São Paulo, do Rio de Janeiro, do Paraná. Este pajé, segundo disse, é ligado à Assembléia de Deus, "mas é coisa indígena mesmo". Conta que a Assembléia de Deus (terena) o procura (ao jovem pajé) "por causa de seu poder excepcional, por causa de seu 'dom', como eles dizem". É também uma frase sua: "Os Terena não têm conflito psicológico" [em função das religiões cristãs com que convivem]. "Os pajés ainda existem, os raizeiros também. Eles ajudam a dar rumo à comunidade".

Por um lado, Jorge reclama para si um investimento, nos objetos culturais aos quais adere, que seja coerente e exclusiva. Nisto, usa os próprios pressupostos de coerência protestante, que usa também para questionar os evangélicos ortodoxos (terena ou não). É esta mesma lógica do outro que utiliza para resistir, para contra ele se rebelar, para ser representativo enquanto sujeito étnico. Poder-se-ia dizer que esse "doutrinamento" é que faz com que Jorge reclame a sua "pureza" terena. Sugeri acima que esta necessidade advém de sua situação limite de indivíduo étnico só, no mundo do outro. Jorge foi alvo das representações do outro que lhe atingiram sem o respaldo comunitário. Para ele também passou a ser uma questão do "tudo ou nada" protestante.

Quando diz, por exemplo, se os Terena realmente "cressem [nos postulados evangélicos], eles não bebiam", está fazendo uso daquele pensamento da coerência. Por outro lado, insinua um investimento terena nestes mesmos objetos evangélicos, mas de forma não exclusivista. Nesta insinuação lança mão também de pressupostos de uma moralidade terena, quando comenta o evangelismo terena. "Cada um tem o que acredita, se eles acham que devem fazer, eu não tenho como impedir". "Ninguém obriga ninguém na aldeia". "O que serve ou não serve para a comunidade, eu não sei. Acho que tem que haver o diálogo, não jogar no medo e na chantagem, na emoção."

Enfim, usa a lógica terena para interpretar os Terena e usa a lógica evangélica para interpretar os evangélicos. $\mathrm{O}$ inverso também acontece.

Segundo a fala de Jorge, o empreendimento missionário pretende ser um erradicador da crença nativa, um discurso sem diálogo, homogeneizador, totalizador. A tradução terena, uma tradução por meio do incomensurável, que estrutura a fala de identidade, descentra este discurso: os Terena transgridem esta totalização na sua maneira coerente de ser inconsistente.

Jorge diz que os Terena são evangélicos, mas no fundo não o são. Roberto Cardoso de Oliveira (op.cit.), preocupado que estava em relacio- 
nar os muitos fatores da assimilação, não deixou de observar que os Terena tinham um "uso exterior" das crenças cristãs:

Entre estes (os Terena), as religiões cristãs penetraram, mas de uma maneira muito mais formal - através de seus cerimoniais - do que como instrumentos novos de interpretação do mundo. Neste sentido, os Terena demonstraram muito realismo, a ponto de não substituírem seu sistema tradicional de crenças pela cosmogonia cristã, quando aquele se quebrou... Exceção, talvez, de uns poucos indivíduos "crentes", para a maioria as novas religiões representaram apenas uma capa, alguma coisa exterior à consciência individual, válida como fonte de status e de papéis que melhor viessem ajustar os indivíduos às novas situações criadas pelas comunidades em mudança (p. 99).

Esta idéia de "capa" é semelhante à idéia do próprio Jorge. No entanto, Jorge não diz que o sistema tradicional "se quebrou". Nem tampouco ocorre em seu discurso falar da pressão exercida sobre sua sociedade como elementos desintegradores, como para o antropólogo. Na ligação entre a representação de Jorge da integração do universo terena e a afirmação de que eles não "sofrem conflitos psicológicos", não está explícito, mas insinuado, o hibridismo terena. Fala aí de um sujeito claudicante, que admite a circulação. Nisto os Terena desafiam a coerência evangélica. Pode-se supor uma mimese e uma tradução nos próprios termos terena do evangelismo missionário.

E o hibridismo de Jorge? Jorge representa o seu hibridismo como não nele próprio, mas nos objetos recolhidos em seu trânsito - a sua noção instrumental das coisas do outro. Assim, as coisas do outro são usadas, mas não são objeto para sua identificação, para a sua auto-representação. Dizer que Jorge se subjetiva investindo na disciplina evangélica, que é também uma afirmação sua, não resolve o problema de encontrar uma ordem sob a qual amarrar o seu discurso. Não consegui disciplinar a conotação do discurso de Jorge no seu ponto mais nevrálgico. Há um hiato na tradução da contraposição entre o ressentimento de Jorge acerca da dominação evangélica e a sua abordagem do evangelismo terena. Não há "conflitos psicológicos". Os pajés e raizeiros estão lá7, como também lá estão os missionários terena. E a Assembléia de Deus, etc. Jorge não poderia levar às últimas conseqüências o discurso da coerência exclusivista para falar em nome do sujeito coletivo terena.

Jorge tampouco é um sujeito isolado de sua comunidade por sua escolha, individual, de abandonar o credo evangélico, contra as expectativas daqueles. Ele é um líder terena. Tenho que supor o entendimento recíproco entre os seus processos e de sua comunidade, se considero o processo de Jorge como particular. 
Eu sou criticado sim pelos evangélicos, mas também me respeitam. Convivo pacificamente com eles. Mas eu acho que muitas vezes eles gostariam de estar no meu lugar.

\section{Notas}

${ }^{1}$ Jorge Miles da Silva, líder indígena conhecido como Jorge Terena, conforme seu povo de origem.

${ }^{2}$ Uma primeira versão deste artigo foi apresentada nas IX Jornadas sobre Alternativas Religiosas na América Latina, em seminário temático que reuniu trabalhos que versam sobre o tema da mútua implicação entre conflitos sociais e práticas religiosas, em 1999.

${ }^{3}$ Entre os estudos que se produziram com esta intenção, muitos deles situando a perspectiva indígena da (e de sua entrada na) história, destacam-se os de Bruce Albert sobre a leitura do contato pelos Yanomami (1992); e a impressionante exegese de Davi Kopenawa do valor da natureza na economia política ocidental, numa demonstração minuciosa do esforço indígena de tradução cultural em meio às ideologias com que tem que se defrontar e negociar, e as incompatibilidades simbólicas que afloram no debate interétnico que entabula (2002).

${ }^{4}$ Ver, por exemplo, os trabalhos sobre emergência ética e etnogêneses em Pacheco de Oliveira (1999) e a introdução deste autor.

${ }^{5}$ Em outro registro que não o da antropologia, autores chamados de pós-coloniais buscam a diferença cultural na implicação entre a fala dominadora e a subalterna, como a dos sujeitos das diásporas que voltam à terra natal sem saber "com que língua falam" (Appiah, 1991); ou as identidades híbridas de que fala Hall, que não serão nem totalmente integradas à nova cultura em que vivem, nem podem retornar totalmente à sua tradição de origem, com quem mantém, entretanto, fortes vínculos (1997, p. 95-6). Lembremos também a crítica de Frantz Fanon (1991) à armadilha dialética da afirmação de uma cultura nativa nos termos de uma cultura colonizadora, que se pretende (ou se impõe como) universal: uma cultura Negra se afirmando como antítese a uma cultura européia. É também instigante a teoria de Bhabha (1994) sobre a incorporação indígena da fala hegemônica do outro nos discursos híbridos da diferença, de um hibridismo tenso e não conciliatório, que revela uma alteridade irredutível e inconciliável, identificada mesmo na imitação, pelo subalterno, do dominador, pois todo colonizado é híbrido, dada a referencialidade recíproca inerente entre centro e margem. Na antropologia, lembremos também de Taussig (1993), para quem o indígena usa e trabalha justamente com e contra o próprio imaginário formado pela conquista por meio do conhecimento proporcionado pela mimesis.

${ }^{6}$ Os primeiros missionários da South American Indian Mission Inc começaram seu trabalho entre os índios Terena em 1912. Em abril de 1972, as Igrejas Evangélicas criadas pela missão no Mato Grosso do Sul fundaram uma união, a União das Igrejas Evangélicas da América do Sul-UNIEDAS. (Estatutos UNIEDAS, p. 2, apud Ferreira, 2007, p. 214-15).

${ }^{7}$ Ferreira (2007), em tese de doutorado recentemente defendida sobre os Terena da Terra Indígena Cachoeirinha, cujos membros são predominantemente católicos, 
considerou axial a relação entre religião e política para a organização social e para a cultura terena, com firme base, ainda, em práticas xamânicas, ou seja, em seus próprios termos. Segundo o autor, "No último período de pesquisa de campo (2004), pudemos identificar um conjunto de pessoas que seriam ou "Koixomuneti/ curandores" ou "benzedores/rezadores", e que indicam, ao contrário deste pretenso desaparecimento de práticas mágico-religiosas, uma ampla difusão delas entre os Terena" (p. 200, grifos do autor).

\section{Referências}

ALBERT, Bruce. A fumaça do metal: historia e representações do contato entre os Yanomami, Anuário Antropológico/89, Brasília, p. 151-89, 1992.

. O ouro canibal e a queda do céu: uma crítica xamânica da economia política da natureza. In: ALBERT, Bruce; RAMOS, Alcida (Orgs.) Pacificando o Branco.São Paulo: ed.Unesp, 2002.

APPIAH, Anthony Kwame. Is the Post- in Postmodernism the Post-in Poscolonial? Critical Inquiry 17, p. 336-57, winter 1991.

ARRUTI, José Maurício. A produção da alteridade: o toré e as conversões missionárias e indígenas. In: MONTERO, Paula. (Org). Deus na aldeia. Missionários, índios e mediação cultural. São Paulo: Editora Globo, 2006.

BHABHA, Homi. DissemiNation: time, narrative, and the margins of the modern nation. In: WILLIANS, Patrick; CHRISMAN, Laura. Colonial Discourse and Post-colinial Theory. New York: Columbia University Press, 1994.

CARDOSO DE OLIVEIRA, Roberto. Do índio ao bugre: o processo de assimilação dos Terena. 2.ed. Rio de Janeiro: Livraria Francisco Alves, 1976.

FANON, Frantz. On National Culture. In: BHABHA, Homi. (Org.) Nation and Narration. 2.ed., London /New York: Routledge, 1991.

FERREIRA, Andrey C. Tutela e resistência indígena: Etnografia e história das relações de poder entre os Terena e o Estado brasileiro. Tese (Doutorado em Antropologia Social) - PPGAS/MN, UFRJ, Rio de Janeiro, 2007.

GALLOIS, Dominique; GRUPIONI, Luis Donisete. O índio na Missão Novas Tribos. In: WRIGHT, Robin (Org.) Transformando os Deuses: os múltiplos sentidos da conversão entre os povos indígenas no Brasil. Campinas: Editora da Unicamp, 1999.

HALL, Stuart. Da Diáspora: identidades e mediações culturais. Belo Horizonte: Ed. UFMG, 2003.

MONTERO, Paula. Missionários, índios e mediação cultural. In: (Org). Deus na aldeia. Missionários, índios e mediação cultural. São Paulo: Editora Globo, 2006.

MOURA, Noêmia; ZORZATO, Oswaldo. O processo de apropriação do protestantismo norte-americano pelos Terena através da UNIEDAS. In: WRIGHT, Robin (Org.) Transformando os Deuses: igrejas evangélicas, petencostais e neopetencostais entre os povos indígenas no Brasil. Campinas: Editora da Unicamp, 2004. 
OLIVEIRA, João Pacheco (Org.). Viagem da Volta: etnicidade, política e reelaboração Cultural no Nordeste Indígena. Rio de Janeiro: Contra Capa, 1999.

RAMOS, Alcida. Indian voices: contact experienced and expressed. In: HILL, Jonathan (Org.) Rethinking history and myth. Indigenous South American perspectives on the past. Urbana: University of Illinois Press, 1988.

Indigenismo de resultados. Revista Tempo Brasileiro, v. 100, p. 133-49, 1990.

WRIGHT, Robin (Org.). Transformando os Deuses: os múltiplos sentidos da conversão entre os povos indígenas no Brasil. Campinas: Editora da Unicamp, 1999.

(Org.). Transformando os Deuses: igrejas evangélicas, petencostais e neopetencostais entre os povos indígenas no Brasil. Campinas: Editora da Unicamp, 2004.

TAUSSIG, Michael. Xamanismo, colonialismo e o homem selvagem: um estudo sobre o terror e a cura. Rio de Janeiro: Paz e Terra, 1993.

VILAÇA, Aparecida. Cristãos sem fé: alguns aspectos da conversão dos Wari (Pakaa Nova). Mana, Rio de Janeiro, v. 2, n. 1, p. 109-37, 1996.

Indivíduos Celestes: cristianismo e parentesco em um Grupo Nativo da Amazônia. Religião e sociedade, Rio de Janeiro, v. 27, n. 1, p. 11-23, jul. 2007.

VIVEIROS DE CASTRO, Eduardo B. O mármore e a murta: sobre a inconstância da alma selvagem. Revista de Antropologia, São Paulo, v. 35, p. 21-74, 1992.

Perspectivismo e multinaturalismo na América indígena, In: $A$

inconstância da alma selvagem e outros ensaios de antropologia. São Paulo: Cosac \& Naify, 2002.

Recebido em 22 de janeiro de 2008.

Aprovado para publicação em 5 de fevereiro de 2008. 